\title{
Public awareness of circular economy in southern Poland: case of the Malopolska Region
}

\author{
Marzena Smol $^{1 *}$, Anna Avdiushchenko², Joanna Kulczycka², Agnieszka Nowaczek ${ }^{1}$ \\ ${ }^{1}$ Mineral and Energy Economy Research Institute, Polish Academy of Sciences, Cracow, \\ Poland \\ ${ }^{2}$ AGH University of Science and Technology, Cracow, Poland \\ *Corresponding author. Tel.: (+48) 12- 617-16-51 (M. Smol) \\ Email address: smol@meeri.pl; smol@min-pan.krakow.pl \\ Address: Wybickiego 7A, 31-261 Cracow, Poland
}

June 2018, Journal of Cleaner Production 197

DOI: 10.1016/j.jclepro.2018.06.100

\begin{abstract}
In the transition to the circular economy (CE) model in Europe, increasing public awareness is one of the major driving forces. This paper presents the results of an evaluation of public awareness and attitudes about CE in the Malopolska region of southern Poland. The data used in this study was collected by random distribution of questionnaires in the Malopolska region and interviews with 430 respondents. Malopolska was chosen for research because the region has significant economic and social potential, but features serious environmental problems primarily air pollution. As environmental protection has become an important aspect for regional and local policy, the $\mathrm{CE}$ concept has already begun to be promoted. The questionnaires distributed to residents were divided into three areas: (1) knowledge and attitudes about CE, (2) CE-related behaviour, and (3) future development of CE in the region. The results show that the CE concept was well recognized mainly by the younger generation, which is more familiar with CE-related behaviours like waste segregation and buying recycled and remanufactured goods. The findings additionally indicate that sharing and collaborative economy practices are becoming popular among residents due to the belief that such services create more economic, environmental, and social benefits for users. People's awareness of the CE concept also has a positive correlation with their educational level, such individuals believing that the CE model could, in the future, be implemented in the region. However, this requires time and additional economic and educational resources.
\end{abstract}

\section{Key words}

circular economy (CE), public awareness, public attitudes, region, questionnaire 


\section{Introduction}

Circular economy (CE) is a global strategy that has been popularized in the European Union (EU) since two communications were published by the Commission of European Communities - the first in 2014, “Towards a circular economy: A zero waste programme for Europe" (COM no. 398, 2014), and the second in 2015, "Closing the loop - An EU action plan for the Circular Economy" (COM no. 614, 2015). These presented a path towards implementation of the CE model in Europe including systemic changes and innovation in technologies, but also changes in organisation, society, finance methods, and policies (COM no. 398, 2014).

One of the major driving forces in the transition to the $\mathrm{CE}$ model is the growing awareness and interest among the public and policymakers of the important role CE can play in delivering smart, sustainable, and inclusive growth, as underlined in the Europe 2020 Strategy (COM no. 130, 2014). Among all the actors (government/public, academic, industry, and citizens) involved in the realisation of CE principles (Carayannis and Campbell, 2012), citizens and their awareness and behaviour have a central position in putting CE concepts into practice.

The building of a responsible CE society requires a deeply ecological culture and societal awareness. Because CE is a new concept in Europe (Elia et al., 2017), it is important to monitor and evaluate public awareness of CE. Special attention should be given to the awareness of the younger generation, as their knowledge, attitudes, and consumption patterns are the most influential for the creation of a CE-oriented society and successful CE implementation as a long-term strategy for development across the EU (Kanchanapibul et al., 2014).

Currently, most research devoted to CE awareness has been conducted in China, e.g. by Xue et al. (2010), Liu et al. (2009), Liu and Bai (2014), and Guo et al. (2017a), where CE has been the main strategy of development at the national level since 2009. According to their research, the current public and business awareness of CE has significantly increased in China (Zeng et al., 2017) in comparison with 2008 when the first study of CE awareness was carried out. In the European Union, the European Commission has started conducting CE-related research for investigation of CE-related business initiatives (Flash Eurobarometer, 2016), but only a small number of CE research papers presented CE public awareness at the EU level (Lakatos et al., 2016), and there is no research focusing on youth awareness.

The term CE is becoming more recognised across Europe and around the world due to numerous promotional actions which have been taken by the EU, China, Japan, other developed countries, and international organisations. The focus of research on public awareness of CE varies depending on the approach that has been adopted in a given region of the world. For 
example, comparative analysis of CE policy in China (Geng et al., 2012; Jiao and Boons, 2017) and Europe (Ghisellini et al., 2016) has shown that they have different focuses framed by different problems. For China, the focus is on general environmental problems and pollution, while for Europe the focus is on materials, resource efficiency, waste, new business models, new jobs, eco-innovations, social innovations, ICT, as well as wider implementation (McDowall et al., 2017). CE in Europe is based on the use of services and intelligent digital solutions, and on the design and production of more durable, repairable, reusable, and recyclable products. Waste is regarded as a valuable resource, and products are shared, leased, or rented, rather than owned by an end user (IISD, 2017).

Many European countries and regions, such as Germany (Liu and Bai, 2014), the Netherlands (A Circular Economy in the Netherlands by 2050, 2015), and Finland (Seppälä et al., 2016) have already launched circular economy plans. In Poland, the government started work on the implementation of CE principles within the national economy in 2016. Currently, the Ministry of Development is working on a national action plan for CE with all the actors of the Quadruple Helix, i.e. government, academic/research units, industry, and NGOs and citizens.

In the present study, three areas related to public awareness of CE were examined - recognition and basic knowledge of CE, CE behaviours, and future development of $\mathrm{CE}$ in the region - in order to examine public awareness about $\mathrm{CE}$ in the selected Polish region, the Malopolska Voivodeship. An evaluation was conducted based on responses to a questionnaire that was prepared on "A circular economy for eco-innovation and sustainable development of the regions". The questionnaires were distributed among a working group of respondents between 18 and 64 years old, mainly with completed or ongoing higher education. This group of respondents may have the largest impact in the transformation to a CE model due to their current activity in the labour market.

The presented survey provides initial insight into the awareness and behaviour of Malopolska residents in the transition to $\mathrm{CE}$ in the region. As the transition to the $\mathrm{CE}$ model in the $\mathrm{EU}$ will be monitored by the European Commission, additional research on public awareness of circular economy needs to be conducted not only in other Polish regions but also in other European countries (COM no. 29, 2018).

\section{Methods and data}

\subsection{Malopolska region}

The Malopolska region is situated in southern Poland. It has an area of 15,108 square kilometres (5,833 sq mi), which in terms of size ranks it among the smallest regions in the country (12th 
place). The region has a population of 3,372,618 (8\% of the country's population), with a population density of 222 persons $/ \mathrm{km}^{2}$. In 2015 a total of 1,634,901 people lived in urban areas. The level of urbanisation is about $48 \%$. Among the 182 municipalities in the region, there are 46 urban and rural municipalities, 14 urban municipalities, and 122 rural municipalities (MOMV, 2016; VIEP in Cracow, 2016). Systematic population growth has been recorded in the region every year, although the rate of growth in recent years has decreased. The structure of the Malopolska region's population is presented in Table 1 according gender, age, and education structure (RSO in Cracow, 2014).

Table 1. Malopolska region resident population structure according to gender, age, and level of education*

\begin{tabular}{|c|c|c|c|}
\hline \multicolumn{2}{|l|}{ Gender } & \multicolumn{2}{|l|}{ Age } \\
\hline Male & $48.5 \%$ & $20-24$ & $10.1 \%$ \\
\hline Female & $51.4 \%$ & $25-29$ & $11.1 \%$ \\
\hline \multirow[t]{2}{*}{ Not specified } & - & $30-34$ & $10.5 \%$ \\
\hline & & $35-39$ & $9.4 \%$ \\
\hline \multicolumn{2}{|l|}{ Education } & $40-44$ & $8.2 \%$ \\
\hline Basic education and lower secondary education & $22.5 \%$ & $45-49$ & $8.1 \%$ \\
\hline Basic vocational education & $24.9 \%$ & $50-54$ & $9.1 \%$ \\
\hline Secondary education & $33.9 \%$ & $55-59$ & $8.7 \%$ \\
\hline \multirow[t]{2}{*}{ Higher education } & $18.7 \%$ & $60-64$ & $7.1 \%$ \\
\hline & & 65 and over & $17.7 \%$ \\
\hline
\end{tabular}

The Malopolska region is one of the most economically developed regions of Poland, which was recognized by the EU with the awards 'European Region of Entrepreneurship 2016', an award from the EU Committee of Regions, and 'RegioStar 2016', an award from the European Commission. Moreover, in 2016 Eurostat ranked the region among the 28 most dynamically developing regions of the EU (MOMV, 2016).

The Malopolska region was chosen for this study because the region has significant economic and social potential, but also features serious environmental problems (MOMV, 2016; VEIP, 2016) including high air quality-related risks (Ośródka et al., 2011). The capital of the Malopolska region is Cracow, which is classed as one of the most polluted cities in the world according to a World Health Organisation (WHO) study. In the WHO report for 2016 (WHO, 2016), Cracow was ranked $8^{\text {th }}$ among 575 cities for high levels of PM 2.5, and $145^{\text {th }}$ among 1,100 cities for levels of PM 10. The problem of high air pollution spans the whole region. At present, the inhabitants are well aware that only synergistic action by regional and national 
government authorities and city residents can improve air quality for Cracow and the surrounding province (Gambuś et al., 2016).

Thanks to numerous actions taken over the last few years, the air quality in the Malopolska region has improved considerably. Cracow nevertheless still ranks among the most polluted European cities. Further activities related to the implementation of environmentally-friendly solutions at the core of the CE model are therefore perceived positively, and this region has high potential for the transformation to $\mathrm{CE}$ in the near future. Regional and local authorities have already started moving toward the implementation of a CE model, including CE aspects in the Waste Management Plan for Malopolska (MVA, 2017). Another document to be updated to introduce CE ideas is the Spatial Management Plan for the Malopolska Region.

\subsection{Research framework}

A key target of the current research was examination of the population's awareness of CE in the Malopolska region and its readiness to think and behave according to CE principles. Special attention was given to working age groups - males aged 18-64, and females aged 18-59. This was also an important opportunity to investigate opinions on future perspectives for $\mathrm{CE}$ in the region, specifically among young and well-educated people upon whom depends the establishment of a future CE-oriented society.

The questionnaire was designed to take into account the European context of the CE concept (Murray et al., 2017), including selected areas of CE such as waste management, water usage, and energy efficiency issues (Saavedra et al., 2018). Those traditional areas of CE are core issues not only in European countries, but also in China, Japan, and South Korea (Geng and Doberstein, 2008; Geng et al., 2012).

As the European CE approach is also strongly focused on eco-innovations, social innovation, ITC technologies, and new business models (McDowall et al., 2017; de Jesus et al. 2017), the European model of CE has initiated new consumption patterns that are especially popular among the working age population, specifically among representatives of the informational and knowledge-based society. Thus, the modern CE consumption model includes "products as service" consumption patterns (Tukker, 2015) and "sharing services" consumption patterns (Toni et al., 2017). Those new trends were also taken into account in preparing the research framework for the current study.

The research framework included approaches to examining public awareness among different target groups as proposed in previous studies (Guo et al. 2017a, b; Lakatos et al., 2016). These were related to public awareness of $\mathrm{CE}$ and widely understood pro-environment behaviour 
(Noorhosseini et al., 2017; Perdana et al. 2017). On this basis, the three following areas were proposed for the current research framework: (1) understanding of CE, (2) CE-related behaviour, and (3) future development of CE in the region (Figure 1). Special attention was paid to CE-related behaviour including sharing and the collaborative economy, waste management, and the use of recycled and remanufactured materials. These sub-areas were chosen based on the developments by McKinsey for a CE framework (the ReSOLVE framework) which takes the core principles of circularity and applies them to six actions Regenerate, Share, Optimise, Loop, Virtualise, and Exchange (Growth Within, 2015).

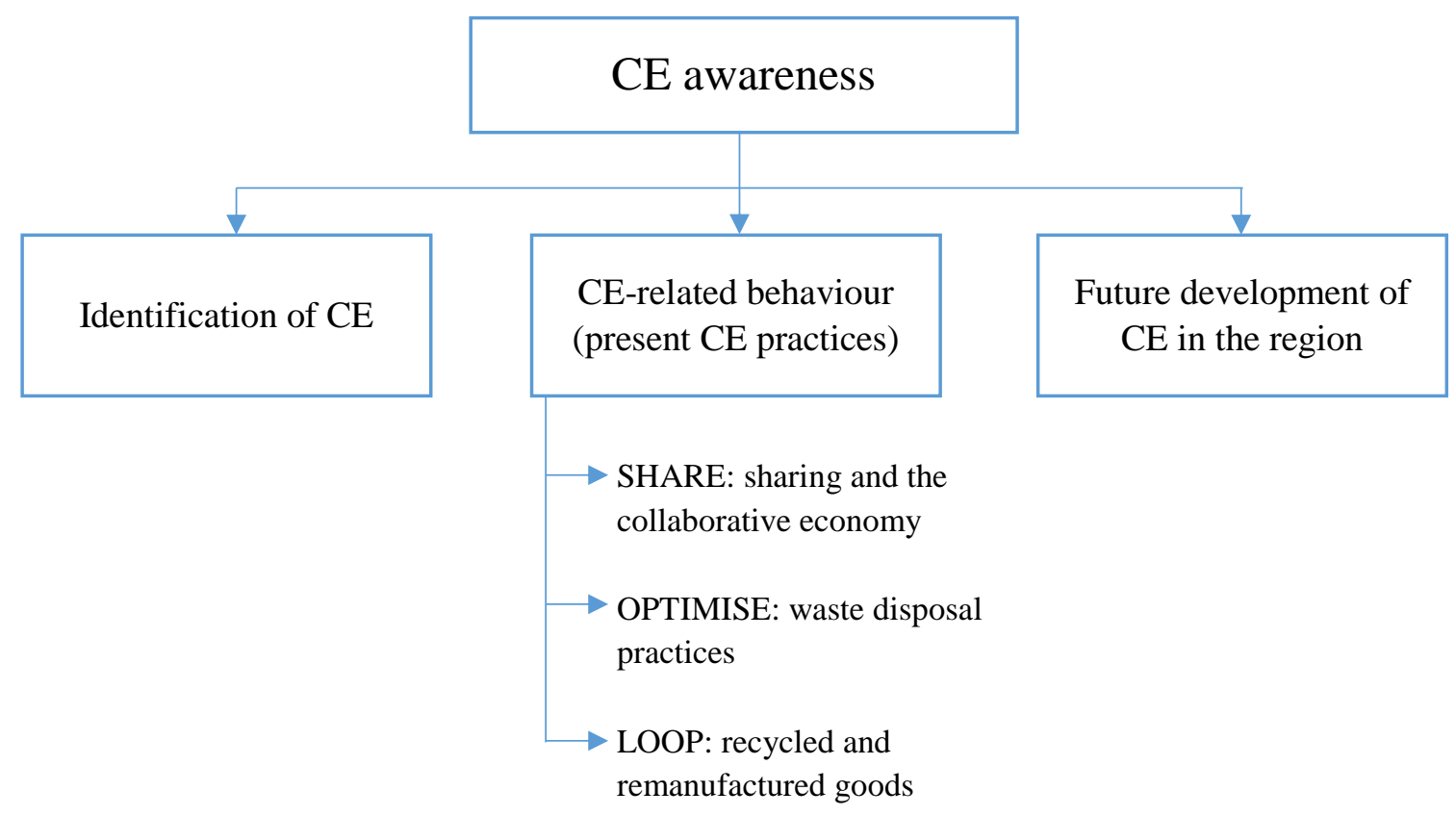

Figure 1. Research framework for CE awareness

\subsection{Survey design and distribution}

The questionnaire for the proposed research framework was designed taking into account the above-mentioned studies on public awareness, and also surveys conducted at the European (Special Eurobarometer, 2014; European Social Survey, 2017) and worldwide levels (World Value Survey, 2017), in order to identify general attitudes and values in societies regarding environmental issues.

The questionnaire consisted of 12 closed questions with single-choice and multiple-choice answers, proposing to respondents particular options related to the definition of circular economy, $\mathrm{CE}$ actions (sometimes they were already engaged in $\mathrm{CE}$ behaviours without being aware that they are CE-related), and the main actors involved in CE implementation in the region. This format was chosen as a method suited to determining the level of knowledge about 
CE, identifying which CE-related actions have already become patterns of behaviour among Malopolska residents, as well as understanding how inhabitants see the future perspectives of $\mathrm{CE}$ in the region. The results are presented in section 3 of this paper.

To determine sample size, the formula for the necessary sample size (n) in the estimation of the fraction of elements distinguished in the population has the form below (Matuszak and Matuszak, 2011):

$$
n=\frac{N}{1+\frac{d^{2}(N-1)}{z_{\alpha}^{2} p q}}
$$

where:

$\mathrm{z}_{\alpha}-1.64$ for $\alpha=0.10$

1.96 for $\alpha=0.05$

2.28 for $\alpha=0.01$

$\mathrm{N}$ - population size

$p$ - expected order of magnitude of the estimated fraction

$\mathrm{q}-1-p$

$\mathrm{d}$ - permissible error of estimate of the fraction $p$ (given in a decimal fraction)

For the estimation, it was assumed: confidence coefficient $1-\alpha=0.95$, thus $\mathrm{z}_{\alpha}=1.96$; maximum error (statistical) $d=0.10 ; p=0.5 ; \mathrm{N}=2,705$ thousands. The calculated sample size was 192 . In total, 430 usable questionnaires were collected. The sample size of 400 is adequate if the target population size is beyond 5,000 (Afroz et al., 2013).

The survey instrument was computer-assisted web interviewing (CAWI). The questionnaire gave the opportunity to identify the respondents' sex, age (only adults were asked to participate in the survey), as well as type and name of the settlement where they live in order to be sure that representatives of all Malopolska sub-regions took part in the survey.

While the main purpose of the research was determining the awareness of working age groups (males aged 18-64, and females aged 18-59) from the region about CE issues, additional attention was paid to the "mobile" working age group (18-44 years old for males and females). They are considered the most influential group for CE implementation and development. It was decided that at least $70 \%$ of respondents should be aged between 18 and 44 years. The opinions of the other age groups of respondents were important to understand differences between generations and how the older generation could support CE implementation across the region. One more important condition for the chosen respondents was the level of education. At least $60 \%$ of the respondents selected were required to have completed bachelor's or master's 
degrees. Thus the chosen sample was not representative of the total population, due to the selective methodology for the sampling. The questionnaire was distributed via social media, the web-page of the institution where the research was conducted, web-pages of Malopolska region municipalities, and the Malopolska Regional Development Observatory. In rural areas, the survey was distributed through cooperation with the Malopolska region Local Partnerships Groups.

\section{Results and discussion}

\subsection{Characteristics of the sample}

In total, 430 questionnaires were completed in the Malopolska region between March and June 2017. The demographic characteristic of the sample is presented in Table 2. As the surveys were conducted in the Malopolska region, which is a leading educational centre in Poland with a large number of university campuses, the survey sample was skewed towards a younger and more educated demographic (Filimonau et al., 2018). Younger Poles were more willing to take part in the study, which was consistent with other research conducted in the Polish context (Dickinson et al., 2013; Filimonau et al., 2018). The selected sample had the following characteristics:

- almost $70 \%$ of the interviewees were in the age range between 18 and 44 years old (age groups of mobility), with the range of 18-24 years (22.3\%) being dominant

- $\quad$ almost $28 \%$ of the interviewees were in the age range between 38 and 50 years old

- $\quad$ about $19 \%$ of interviewees were between 51 and 64 years old

- $\quad 2.6 \%$ of interviewees were older than 65

The next important condition for choosing the sample was the level of education, thus the following characteristics of the sample were obtained:

- the majority of the respondents (64.9\%) had completed a bachelor's or master's degree

- $\quad 27.7 \%$ of respondents had reached the level of secondary education, and $7 \%$ had achieved a basic vocational education

- less than $1 \%$ of interviewees had relatively lower education levels, namely with lower high school (gimnazium) diplomas or a basic education level $(0.7 \%)$

Table 2. The demographic characteristics of the sample $(n=430)$ 


\begin{tabular}{lrrrr}
\hline Male & $33.7 \%$ & & $18-24$ & $22.3 \%$ \\
Female & $66.3 \%$ & & $25-30$ & $10.7 \%$ \\
Not specified & - & $31-37$ & $18.1 \%$ \\
\cline { 1 - 1 } Education & & $38-44$ & $15.8 \%$ \\
\cline { 1 - 1 } Basic education and lower secondary education & $0.7 \%$ & & $51-56$ & \\
Basic vocational education & $7.0 \%$ & & $57-64$ & $9.5 \%$ \\
Secondary education & $27.7 \%$ & & 65 and over & \\
Higher education & $64.6 \%$ & &
\end{tabular}

\subsection{Consumer knowledge about $\mathrm{CE}$ issues (understanding of CE)}

In the first stage of the research, the respondents were asked about their understanding of and attitude towards CE. The results are presented in Figures 2-3. Protecting natural resources by keeping materials in circulation and minimising their losses in the form of waste were indicated as a core $\mathrm{CE}$ characteristic by the majority (78\%) of participants. CE means closing production loops in industry for almost $11 \%$ of respondents. For the same proportion of the sample, $\mathrm{CE}$ is related to the segregation of waste in households.

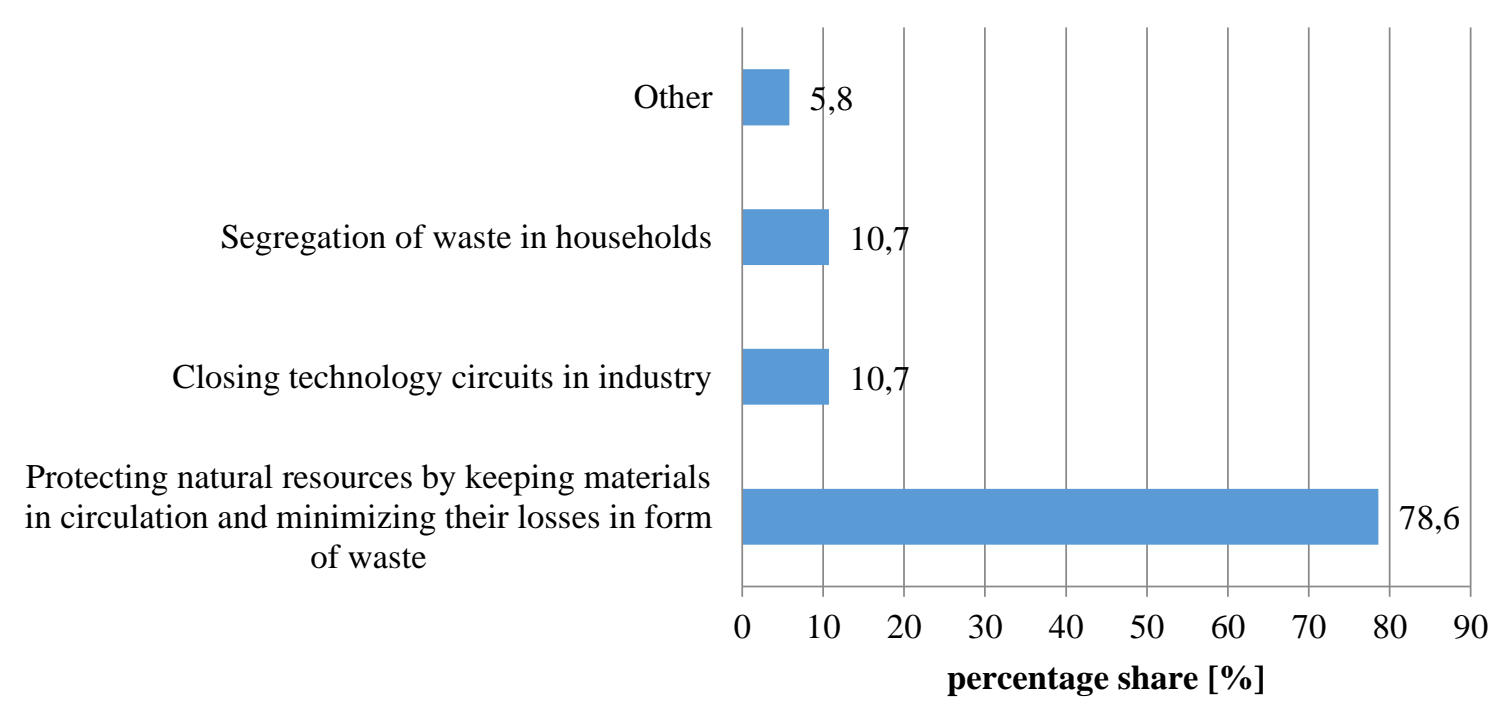

Figure 2. Understanding of the term "circular economy" (multiple choice)

The second question in this section was related to the application of the circular economy in everyday life. For almost $79 \%$ of respondents, the principles of CE could be implemented both in business and by private individuals. More than $14 \%$ of respondents associated the role of CE in production activities with the ability of companies to recycle materials in production cycles. 
For approximately $7 \%$ of those surveyed, respondents believed citizens are responsible for the realisation of the concept of the $\mathrm{CE}$ by reducing consumption and by proper waste segregation.

Across the economy (both by businesses and private individuals)

Only by private individuals as a result of the reduction of consumption and waste segregation

Only in production areas, companies have the ability to recycle materials in technology cycles

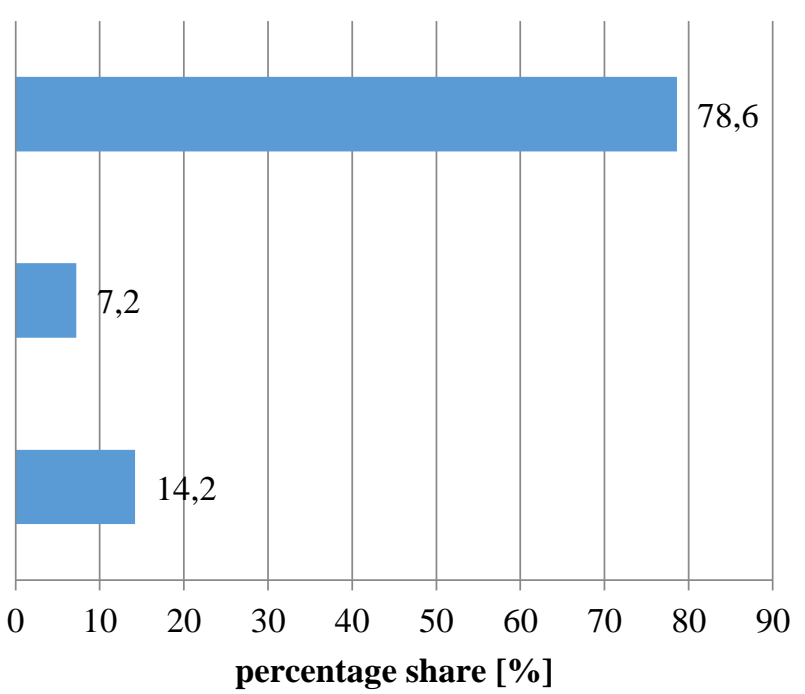

Figure 3. Application of circular economy in everyday life

Based on an evaluation of the education level of the respondents and the works of other authors such as Guo et al. (2017b) or Liu et al. (2009), it should also be noted that the understanding of the term "circular economy" could confirm that people's CE awareness has a positive correlation with their level of education. In the present study, 93\% of the respondents have either higher education (64.9\%) or secondary education $(27.7 \%)$.

The present analysis shows public recognition of CE is at a satisfactory level in Malopolska. Although the term $\mathrm{CE}$ is new to citizens, the CE concept was well recognized and connected with raw materials conservation and waste prevention. As described earlier, the idea of $\mathrm{CE}$ has become increasingly popular in the EU since 2014, when the first communication "Towards a circular economy: A zero waste programme for Europe" (COM no. 398, 2014) was published, followed by an action plan in 2015 (COM no. 614, 2015). It was at this time when the term "circular economy" and the concepts behind it were also starting to be popularised in Poland (Smol et al., 2017).

The Polish government began work on the implementation of CE principles for the national economy in 2016. Under the Polish Ministry of Development, the Interdepartmental Circular Economy Group set up four working groups focused on waste, bio-economy, business models, and soft actions (dissemination and education activities). The involvement of all actors from the Quadruple Helix (government, academia, industry, and NGOs and citizens), including experts from the Malopolska region, may help explain why the understanding of the CE concept and its relationship with both business and the public are known by approx. $80 \%$ of respondents. 


\subsection{CE-related behaviour (present CE practices)}

The behaviour of all consumers is a significant factor in the passage from a linear to a circular economy. Thus, an evaluation was conducted examining current CE-related behaviour. The areas of CE-related behaviour were divided into sub-areas such as recycled and remanufactured goods, products as services consumption, and waste disposal practices. The findings on public behaviour are presented in Figures 4-8.

\subsubsection{Sharing and the collaborative economy}

In many respects, a circular economy is based on a sharing economy, i.e. obtaining, giving, or sharing access to goods and services (Hamari et al., 2016). The research findings on respondents' behaviour with regard to the 'sharing economy model' are presented in Figures 4 and 5.

The respondents indicated that half of them use services for the sharing of journeys like BlaBlaCar, Uber, etc., and use housing/room rental services directly from the owners like Airbnb, Couchsurfing, and other platforms. Moreover, $22 \%$ of respondents believe that such services are cheaper than traditional offers, and for $29 \%$ they offer a desirable combination of price and quality. However, the second half of interviewees do not use sharing services for journeys and flat renting, of which $32.3 \%$ do not trust this kind of service and $18.6 \%$ have never heard about them.

The results also confirm that citizens still do not prefer goods proposed for hire like using a city bike or renting a car. Almost $70 \%$ of respondents do not use such services. This is because they did not know of such a possibility (7.2\%), they think renting is more expensive than having something of one's own (32.1\%), and for some of them, they live in places where there is no possibility of hiring goods/products $(28.6 \%)$. In total $12.6 \%$ of respondents think that such services create more economic benefits for them and that this approach contributes to greater economic, environmental, and social benefits. 
No, because I do not trust such services

No, I have never heard of such services

Yes, because such sites offer cheaper services compared to traditional offers

Yes, I believe that this is a good combination of price and quality of services received

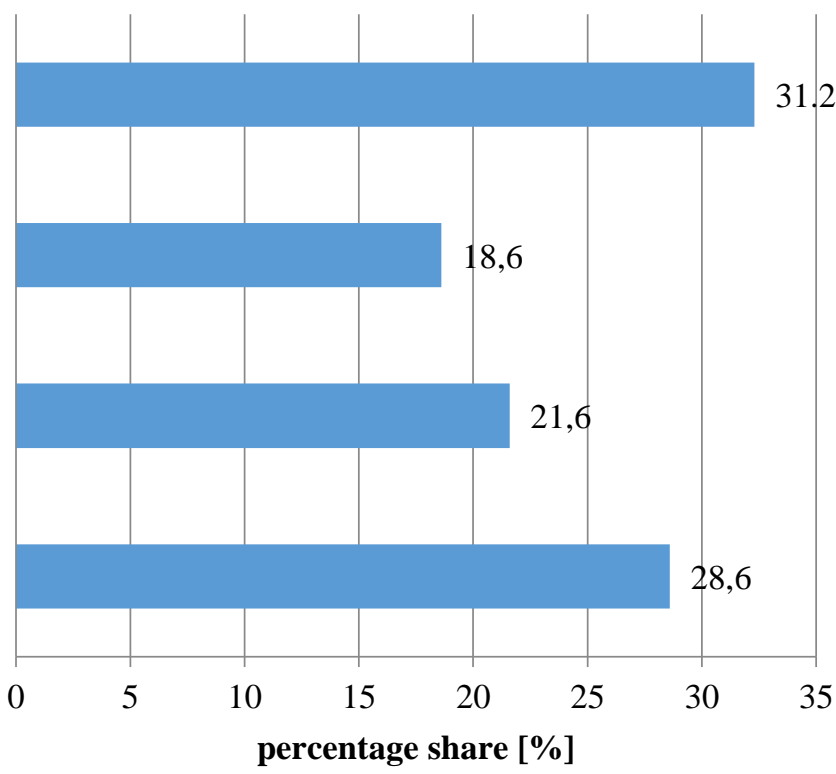

percentage share [\%]

Figure 4. Use of services for sharing journeys or housing/room rental directly from the owners

No, because I have never heard of such possibilities

No because in the town where I live, there is no possibility of hiring goods / products

No, because I think renting is more expensive than having something to own

Yes, because this approach contributes to greater economic, environmental and social benefits

Yes, because I think they create more economic benefits

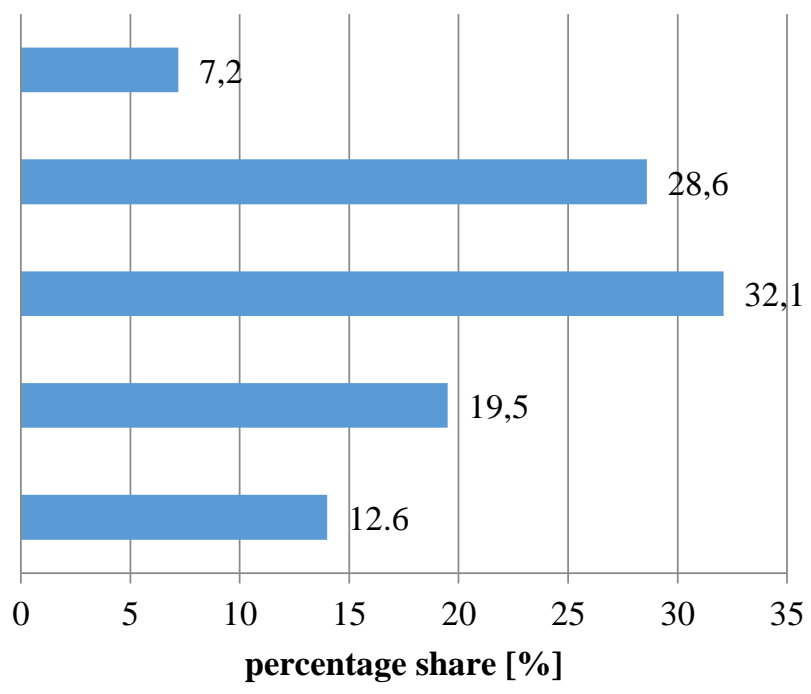

Figure 5. Use of goods proposed for hire/renting

The sharing economy is related to many aspects of life, including the possible sharing of services and goods. This phenomenon is expected to expand and grow steadily in the coming years (Ferrari, 2016). However, based on the current findings, it can be observed that people have different approaches to the sharing of services and sharing of goods. More than half of the people surveyed in the Malopolska region already use a sharing service - for example Uber for taxi services, Traficar, BlaBlaCar for sharing journeys, or Airbnb, Couchsurfing, etc. for renting of houses/rooms directly from the owners. Moreover, this group of respondents strongly believes that such services create more economic, environmental, and social benefits for users. 
There are still many possibilities for the creation of new practices for the sharing economy, like the sharing of clothes, kitchen equipment, garden devices, etc. In the work of Hamari et al (2016), the authors indicate that in the model for the sharing economy, sustainability might only be an important factor for those people for whom ecological consumption is important. The indepth results suggest that an attitude-behaviour gap might exist in 'Collaborative Consumption' (CC). People perceive the activity positively and find good things about it, but this good attitude does not necessarily translate into action.

\subsubsection{Waste disposal practices}

Waste disposal practices are one of the most important factors in the implementation of $\mathrm{CE}$ principles in households. In the Malopolska region, almost $67 \%$ of respondents indicate that they segregate waste at home. Approximately $17 \%$ of interviewees usually selectively collect waste, and $8.4 \%$ rarely conduct waste separation. Only $5.1 \%$ and $3.5 \%$ respectively of the respondents never or sometimes practice this solution for waste disposal.

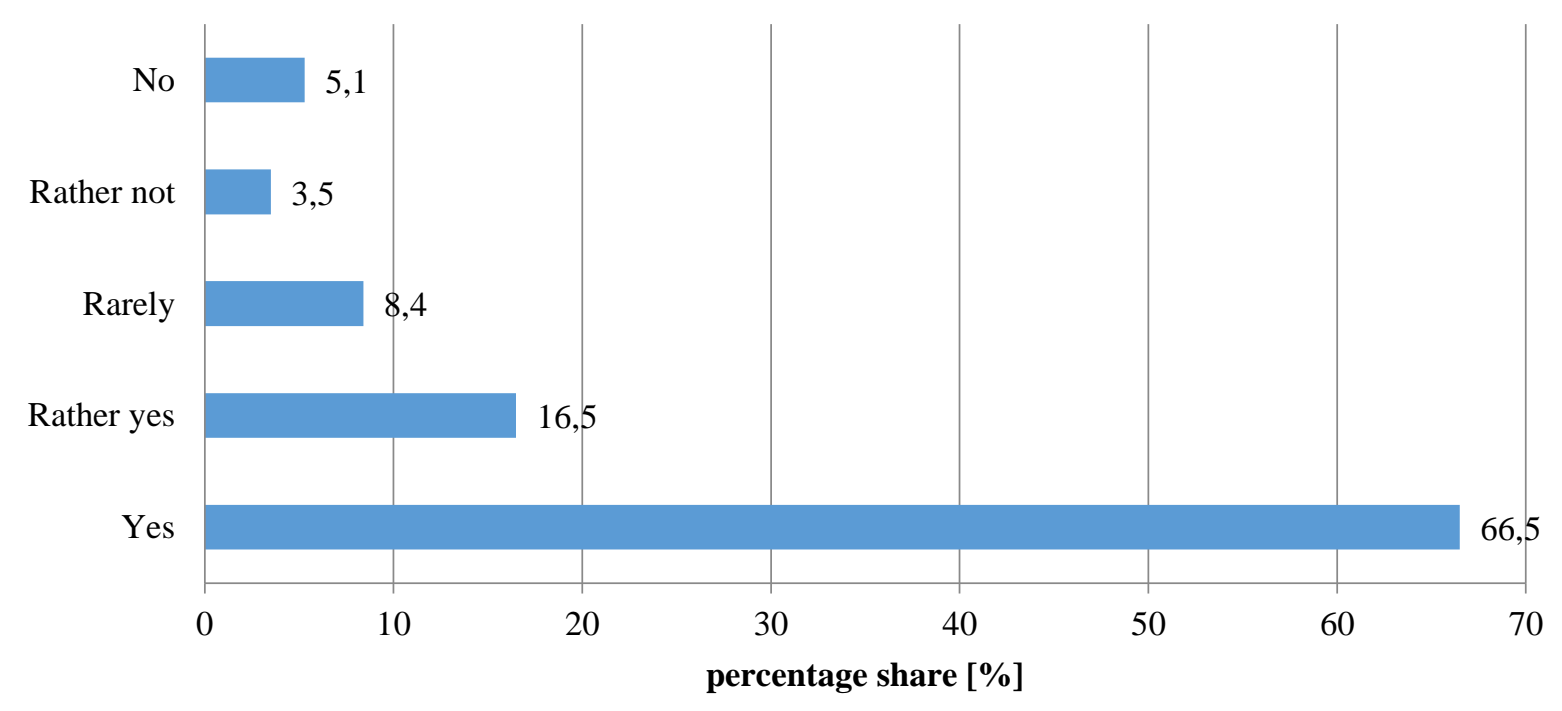

Figure 6. Waste segregation at home

One other issue in the transition to $\mathrm{CE}$ relates to food disposal practices. The interviewees were asked about the percentage of food which goes to waste in their households (Figure 7). Less than $1 \%$ of respondents indicate that more than half of their food is thrown into the waste bin in their houses. Less than $30 \%$ of food is wasted in almost $87 \%$ of households surveyed, and $53 \%$ of all respondents are wasting less than $10 \%$ of food. 


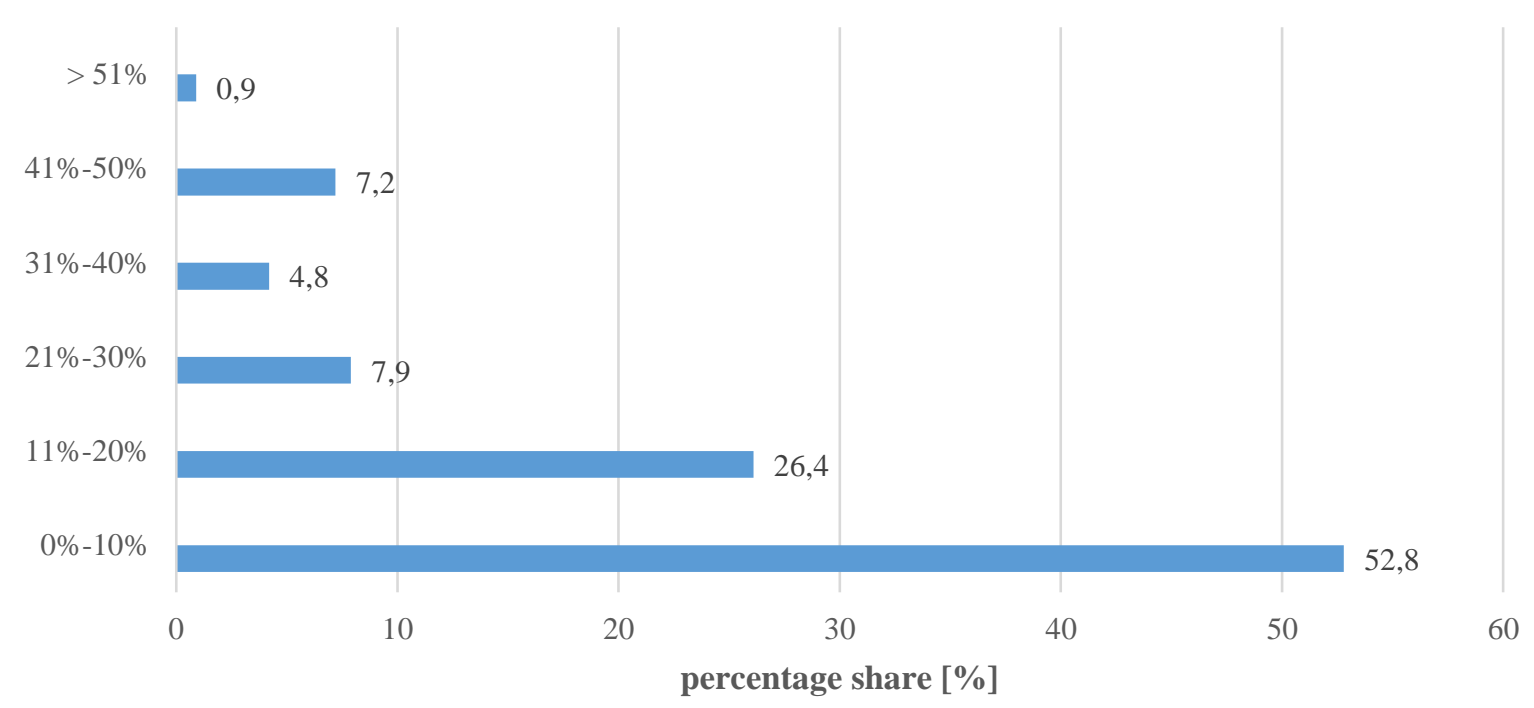

Figure 7. The share of food bought and wasted in households

Currently, waste management is one of the most important priorities in the economy of the European Union (Generowicz et al., 2011), as well as other European countries and around the world (Kulczycka et al., 2016). One of the main goals of the EU is to achieve sustainable development in waste management leading to a reduction in its generation and safe recovery, according to "A zero waste programme for Europe" in which it is stressed that sustainable economic growth is possible through transition to a circular economy model. CE systems keep the added value in products for as long as possible and eliminate waste.

Moving towards a more circular economy is essential to deliver the resource efficiency agenda established under the Europe 2020 Strategy (COM no. 398, 2014). It is assumed that sustained improvement in resource efficiency is achievable and can bring significant economic and social benefits to EU Member States, including Poland. This is one of the key elements of the Europe 2020 resource-saving initiative for smart, sustainable, and inclusive growth.

Waste management issues are indicated as a core of the CE model not only by the European Commission (COM no. 398, 2014) but also by many other authors, such as the Ellen MacArthur Foundation (Growth Within, 2015), Cobo et al. (2017), Homrich et al. (2017), Iacovidou et al. (2017), etc.

In Poland, the most important regulation on waste disposal is the Act on Waste (Journal of Laws 2013, item. 21). According to the provisions in this regulation, the following waste management hierarchy is being introduced:

1) preventing waste generation

2) preparing waste for reuse

3) waste recycling 
4) other waste recovery

5) waste disposal

Society is the "manufacturer" of municipal waste in households. According to a regulation introduced into the Polish waste management system in 2013 (Journal of Laws 2013, item. 1399), municipalities are responsible for collection of all wastes from all inhabitants. All property owners are obliged to indicate if they selectively or non-selectively collect waste in their households. The property owner is also required to pay a fee, the amount of which is also determined by the municipality. The municipal council determines this fee by way of a resolution that is an act of local law (Rakoczy, 2014). The fee also depends on the number of people living in the household and the way that waste is collected by the owners - the fee is higher for people who do not segregate the waste before disposal.

Based on the present research, it can be concluded that the residents of the Malopolska region pay attention to waste disposal practices; two thirds of the people surveyed indicate that they segregate waste at home. However, national statistics do not confirm this phenomenon to such a large extent. Based on data provided by the Central Statistical Office (CSO Environment 2013, 2014, 2015, 2016), the amount of municipal waste collected in the Malopolska Voivodship increased from 473 thousand tonnes in 2012 to 795.5 thousand tonnes in 2015, with the amount of mixed waste constantly decreasing (Table 3). Although decreasing, the percentage share of mixed waste still remains at a high level - in 2015 it constituted $76 \%$ of all municipal waste collected from households in the Malopolska Voivodship.

Table 3. Municipal waste collected from households in the Malopolska Voivodship from 20122015 (CSO Environment 2013, 2014, 2015, 2016)

\begin{tabular}{c|c|c|c|c}
\multirow{2}{*}{ Year } & \multicolumn{2}{c}{ Grand total } & \multicolumn{2}{c}{ Mixed } \\
\cline { 2 - 5 } & in thous. tonnes & in kg per capita & \multicolumn{1}{c}{ in thous. tonnes } & \% of total \\
\hline 2012 & 473 & 141.3 & 397 & 83.9 \\
\hline 2013 & 520 & 155 & 432 & 83.1 \\
\hline 2014 & 764 & 227 & 599 & 78.4 \\
\hline 2015 & 795.5 & 236 & 605.4 & 76.1
\end{tabular}

Food disposal practices are also increasingly frequently taken into account during the transition to the CE model. In the Malopolska region, the amount of biodegradable waste collected, mainly in the form of food waste in households, increased from 10 thousand tonnes in 2012 to 
49.7 thousand tonnes in 2015 (CSO Environment 2013, 2016). As noted earlier, more than half of the interviewees indicated that they are wasting less than $10 \%$ of the food in their households. One of the ways to save food is to introduce the concept of the sharing economy into everyday life. This concept currently plays an important role in trying to achieve CE goals within the food sector. For example, there are over 700 food-sharing points in Germany. These are places where people can bring food, as well as offer products provided by others. Currently, there are three food-sharing points in Warsaw, and one was opened in Cracow at the end of 2016. The idea of food sharing is more and more popular in Europe. Various initiatives and start-ups are being developed all over the world involving the collection and use of excess food from consumers and retailers, and the promotion of collaborative models of consumption (Falcone, Imbert, 2017).

\subsubsection{Recycled and remanufactured goods}

Almost half of the respondents $(49.5 \%)$ have no problem with buying recycled products in preference to others. They did indicate that this decision depends on the type of products, e.g. they prefer to buy toilet paper made from recycled materials. One third of interviewees $(34.2 \%)$ do not pay attention to the origin of the products when buying, and 5.6\% have a negative attitude toward such products. More than $10 \%$ of the respondents support the sales of products from recycling and always choose these kind of goods. Almost the same number of respondents (9.5\%) always buy remanufactured goods such as car tyres, re-circulated cell phones, and other items. The interviewees indicate that in the case of remanufactured products, it is important to get a lower price and guarantee when buying. Such factors are a condition of choosing these products for more than $45 \%$ of respondents. In total, $32.8 \%$ of people surveyed do not pay attention to such options and never buy this kind of product. Moreover, for $12.1 \%$ of respondents, price is the most important factor when buying remanufactured goods. 
No, I have a negative attitude towards such goods and I never buy them

I do not pay attention to the origin of the product

It depends on the type of product

Yes, I always buy such products

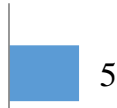

5,
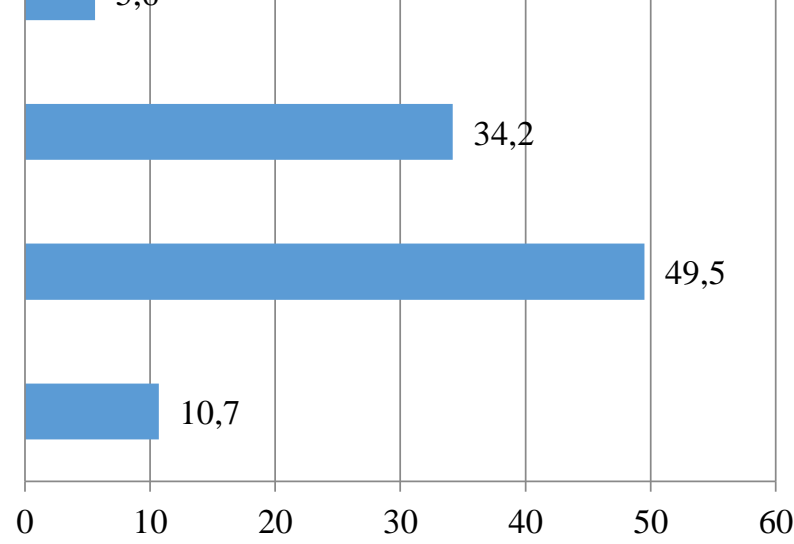

percentage share $[\%]$

Figure 8. Purchase of recycled products over others

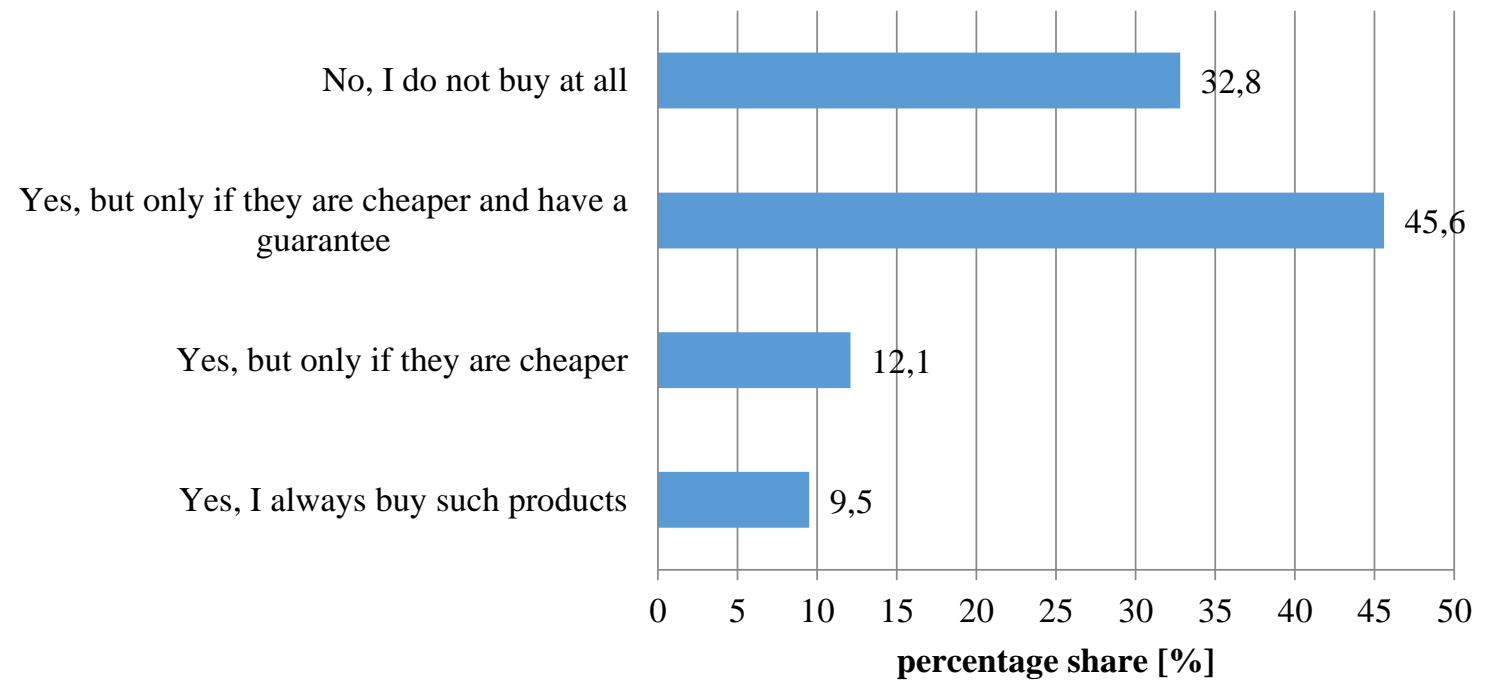

Figure 9. Purchase of remanufactured goods over others

Global extraction of natural resources has risen over time, and is expected to increase in the future (Sonnemann et al., 2015). In order to prevent resource depletion, recycling, re-use, and re-manufacturing of goods is promoted by the EU. The evaluation of public behaviour involving recycled and remanufactured products shows that people are interested in such products. However, they indicate that their decision to buy or not to buy usually depends on some extra benefits like an additional guarantee and a lower price. One third of the people in the Malopolska region surveyed never pay attention to such benefits and never buy this kind of product. Some people always support the sales of products from recycling or remanufactured goods and always choose this kind of good. The price of such products is an important factor 
when buying, and economic factors often outweigh the origin of the product. Meanwhile, consumer choices are one of the most important instruments of environmental impact.

The main direction of change in this area is consumer education aimed at changing consumer behaviour by raising awareness among users of goods and services, improving their access to products and product information, and ensuring the safety of the products offered. Consumer behaviour at the selection stage of products and services can be crucial for the implementation of a CE model. Ecological awareness surveys indicate that Poles are aware of the dangers of overuse of resources. Yet they do not know practical ways of preventing this phenomenon from occurring by changing the ways they think and behave as consumers - the potential of buying products according to those products' ecological specifics and, as a result, putting pressure on producers (Roadmap Transformation towards a circular economy, 2017).

\subsection{Building of $\mathrm{CE}$ awareness and its future development in the region}

The residents of Malopolska were asked if they believe that the CE model could be implemented in the region in the future. For more than $80 \%$, the implementation of $\mathrm{CE}$ principles is possible, although $29.3 \%$ of respondents think that it will take a long time, and $30.2 \%$ indicate the necessity of additional financial support for it. Some of the respondents (10.4\%) do not believe that it is possible and accord economic considerations more importance than CE principles. Approximately $12 \%$ of interviewees do not have an opinion on the transition to the CE model in Malopolska.

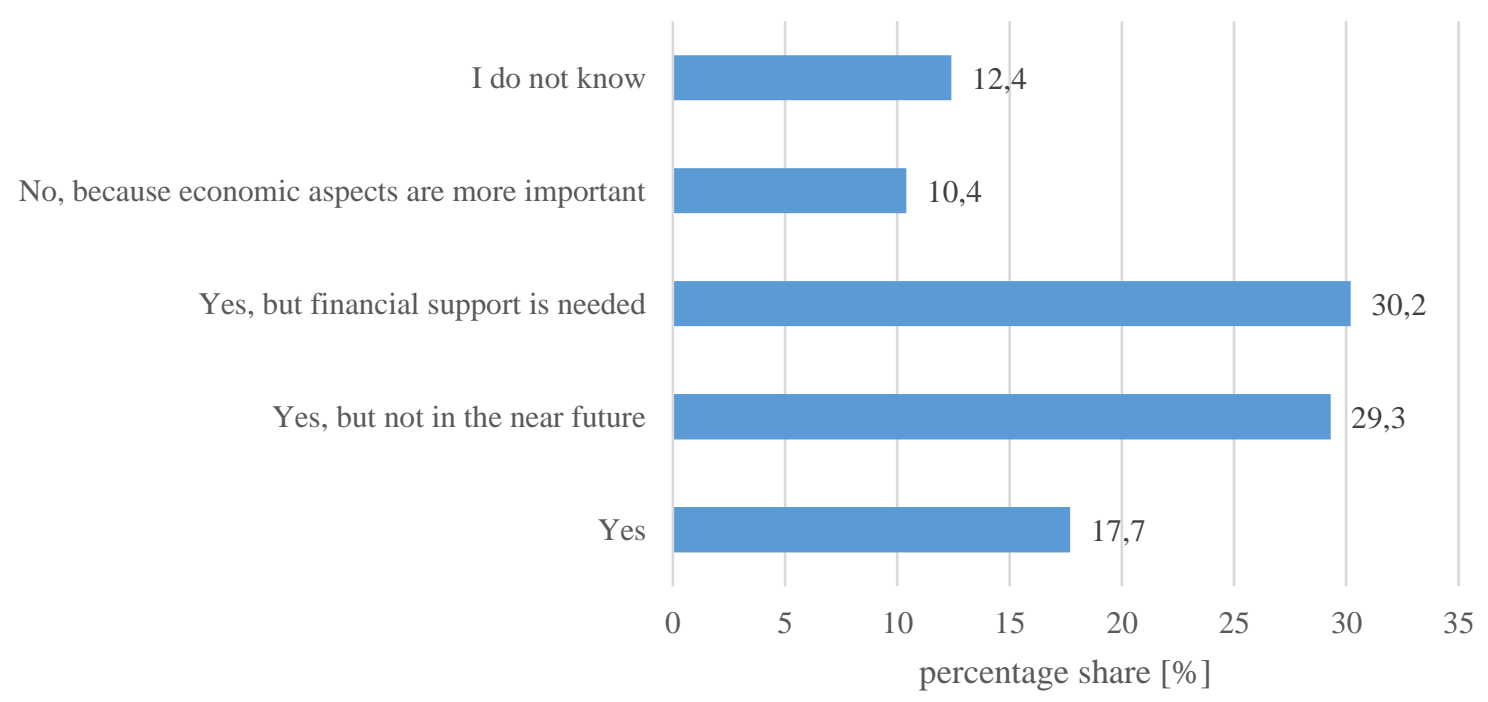

Figure 10. Opinion of the inhabitants of Malopolska on the development of CE in the region 
One of the crucial challenges for the implementation of CE assumptions in everyday life is raising awareness among the region's inhabitants. The development of $\mathrm{CE}$ actions in the region requires the involvement of all participants in the ecosystem. Based on the current study, society is open to transition to the CE model and mostly believes that a CE strategy could be implemented in the region. However, it may take time to change people's way of thinking and behaviour, and some financial support should be provided by national and regional governments.

To help build CE awareness among the community, the Ministry of the Environment shares educational materials with both lecturers and students. One of the elements of the work of the Interdepartmental Circular Economy Group is also dedicated to educational activities. Education will be implemented in all target groups (children, youth, students, community, entrepreneurs, and officials). The aim is to shape the attitudes of consumers, helping them to gain experience in developing optimal patterns of behaviour in the marketplace.

The proposals for action in this direction are indicated in the Polish roadmap 'Transformation towards a circular economy', prepared by the Ministry of Development. The main proposals are as follows: the creation of an internet platform which enables the exchange of information among the elements of the Quadruple Helix; the promotion of sustainable consumption patterns in children/youth education and higher education; the inclusion of topics related to rational resource management, clean technology, energy efficiency, green jobs, and corporate social responsibility (CSR) in the general curriculum; a social campaign on patterns of sustainable consumption; and dissemination of knowledge about CE in municipalities. Such actions have already been implemented in selected municipalities that are taking part in the 'CE Pilot Priority Programme'.

In Poland, responsibility for the creation of CE awareness in the region is also one of the tasks of the Ministry of the Environment and the Ministry of Development. In 2016, the 'CE Pilot Priority Programme' was implemented in five municipalities - Krasnobród, Łukowica, Sokoły, Tuczno, and Wielun - supported by the National Fund for Environmental Protection and Water Management (Towards a Circular Economy, 2016). The main objective of the programme is the development of best practices in the scope of transition towards a circular economy in the selected Polish municipalities. A further stage is an exchange of views and knowledge transfer to other regions. The models of municipal management promoting a circular economy will thus be transferred to other Polish communities.

The path towards the implementation of CE has already been initiated by the Malopolska region through its active partnership in the international project 'Industrial Symbiosis for Regional 
Sustainable Growth and a Resource Efficient Circular Economy' (SYMBI). The project will contribute to improving the implementation of regional development policies and programmes related to the promotion and dissemination of Industrial Symbiosis and the Circular Economy from seven participating countries faced with aligning their policies with the CE strategy of the European Commission to transform Europe into a more competitive, resource-efficient economy (interregeurope.eu/symbi).

\section{Conclusions}

The CE concept recently became popular in Poland at the national and regional levels as a model supporting more sustainable development. The Malopolska region is one of the most dynamically developing within the country, with a high potential for technical and social innovations, but at the same time having environmental problems caused inter alia by air pollution and difficulties in the implementation of effective waste management systems. Malopolska authorities have begun to discuss and introduce CE principles into regional development policies - one of the first regions in the country to do so. That is why an analysis of public awareness of CE concepts, attitudes, behaviours, and future prospects for CE development among the local population is supportive of CE progress within the region. This research has revealed the following trends in the public's awareness of CE issues in Malopolska:

- $78.6 \%$ of respondents identified CE with protection of raw materials and waste management, and $76.6 \%$ expressed the opinion that CE could be implemented both by business and by individuals

- sharing and collaborative economy practices are not especially popular among respondents, and about $70 \%$ of them have never used such services

- the majority of respondents take responsibility for the waste they generate, with $66.5 \%$ of respondents always segregating waste, and $52.6 \%$ wasting less than $10 \%$ of food in their household

- CE practices such as buying products made from recycled materials and remanufactured goods are quite popular - more than $60 \%$ of respondents buy such products when additional conditions are met (lower price and extended guarantees)

- most respondents (80\%) see future prospects for the development of CE in the Malopolska region (in the long term, if some financial support is provided) 
The general picture presented by this survey is that the CE model is relatively understandable for the majority of respondents, as indicated by analysis of CE-related behaviour. At the same time, some practices could still be better implemented and promoted at the regional and local levels. These findings are valuable for all stakeholders involved in the regional process of CE development, its promotion, and its successful realisation.

As attitudes and behaviours are shaped at different levels, further funding of such research could be used by local and regional authorities, local communities, and NGOs with an environmental and innovative focus to prepare CE strategies, action programmes, and plans designed to increase public awareness of CE issues. Moreover, the obtained results can be expected to contribute to the wider international debate about $\mathrm{CE}$, as greater public awareness about $\mathrm{CE}$ is one of the main conditions for the creation of a circular-oriented society in Europe.

Existing research devoted to $\mathrm{CE}$ awareness issues in European countries is quite limited. The findings of the current case study are particularly valuable for policymakers and industry to understand just how effective their CE promotion actions and instruments are at shaping the transition to a CE model of development. The research framework prepared for this study could be adapted for doing CE-related research in other European regions and elsewhere in the world. It could also be helpful for examining the relationship between public awareness about CE and progress toward realizing a circular economy in specific regions.

\section{Acknowledgements}

This study was supported by the project "The Circular Economy Conception Towards Ecoinnovations and Sustainability of Regions" (ce4reg). This project received funding from the European Union's Horizon 2020 research and innovation programme under the Marie Skłodowska-Curie grant agreement No 665778, as well as the National Science Centre, Poland, POLONEZ funding programme. Project registration number 2015/19/P/HS4/02098.

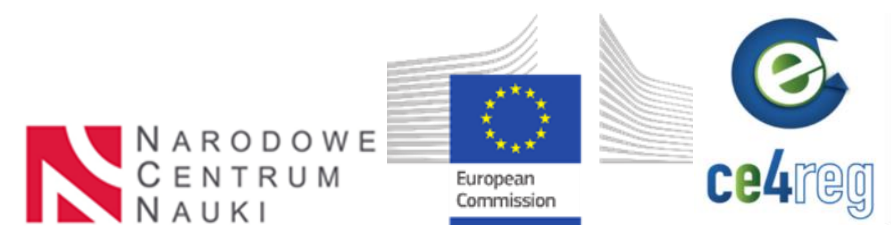




\section{References}

1. A Circular Economy in the Netherlands by 2050, Government-wide Programme for a Circular Economy, The Ministry of Infrastructure and the Environment and the Ministry of Economic Affairs, also on behalf of the Ministry of Foreign Affairs and the Ministry of the Interior and Kingdom Relations, Netherlands 2016, (A Circular Economy in the Netherlands by 2050, 2015).

2. Act on Maintaining Cleanliness and Order in Municipalities (the act applies to municipal waste) of 13 September 1996 (Journal of Laws 2013, item 1399) (in Polish).

3. Act on Waste of 14 December 2012 (Journal of Laws 2013, item 21) (in Polish).

4. Afroz, R., Masud, M. M., Akhtar, R., Duasa, J. B. 2013. Survey and analysis of public knowledge, awareness and willingness to pay in Kuala Lumpur, Malaysia-a case study on household WEEE management. Journal of Cleaner Production, 52, 185-193.

5. Carayannis, E. G., Campbell, D. F. 2012. Mode 3 knowledge production in quadruple helix innovation systems. In Mode 3 Knowledge Production in Quadruple Helix Innovation Systems (pp. 1-63). Springer New York, DOI: 10.1007/978-1-4614-2062-0_1.

6. Central Statistical Office, Environment 2013, 2014, 2015, 2016 (CSO Environment 2013, 2014, 2015, 2016)

7. Cobo, S., Dominguez-Ramos, A., Irabien, A. 2017. From linear to circular integrated waste management systems: A review of methodological approaches Resources Conservation \& Recycling. doi.org/10.1016/j.resconrec.2017.08.003.

8. Commission of European Communities. Communication No. 130, 2014. Taking stock of the Europe 2020 strategy for smart, sustainable and inclusive growth (COM no. 130, 2014).

9. Commission of European Communities. Communication No. 398, 2014. Towards a circular economy: A zero waste programme for Europe. (COM no. 398, 2014).

10. Commission of European Communities. Communication No. 614, 2015. Closing the loop An EU action plan for the Circular Economy. (COM no. 614, 2015).

11. Commission of European Communities. Communication No. 29, 2018. Monitoring framework for the circular economy. (COM no. 29, 2018).

12. de Jesus, A., Antunes, P., Santos, R., Mendonça, S. 2018. Eco-innovation in the transition to a circular economy: An analytical literature review. Journal of Cleaner Production, 172, 2999-3018.

13. Dickinson, J. E., Robbins, D., Filimonau, V., Hares, A., Mika, M. 2013. Awareness of tourism impacts on climate change and the implications for travel practice: A Polish perspective. Journal of Travel Research, 52(4), 506-519. 
14. Elia, V., Gnoni, M. G., Tornese, F. 2017. Measuring circular economy strategies through index methods: A critical analysis. Journal of Cleaner Production, 142, 2741-2751.

15. European Social Survey, 2017, www.europeansocialsurvey.org (European Social Survey, 2017).

16. Falcone, P. M., Imbert, E. 2017, Bringing a Sharing Economy Approach into the Food Sector: The Potential of Food Sharing for Reducing Food Waste. In Food Waste Reduction and Valorisation, 197-214.

17. Ferrari, M. Z. 2016. Beyond Uncertainties in the Sharing Economy: Opportunities for Social Capital. European Journal of Risk Regulation, 7(4), 664-674.

18. Filimonau, V., Mika, M., Pawlusiński, R. 2018. Public attitudes to biofuel use in aviation: Evidence from an emerging tourist market. Journal of Cleaner Production. 172, 3102- 3110.

19. Flash Eurobarometer 441-TNS Political \& Social, 2016 ec.europa.eu/environment/greengrowth/.../fl_441_sum_en.pdf (Flash Eurobarometer, 2016).

20. Gambuś, F., Gorczyca, O., Koncewicz-Baran, M., Wieczorek, J. 2016. An introduction to the subject of fighting against smog in Cracow. Aura, (9), 3-7.

21. Generowicz, A., Kulczycka, J., Kowalski, Z., Banach, M. 2011. Assessment of waste management technology using BATNEEC options, technology quality method and multicriteria analysis. Journal of Environmental Management, 92(4), 1314-1320.

22. Geng, Y., Doberstein, B., 2008. Developing the circular economy in China: challenges and opportunities for achieving "leapfrog development". International Journal of Sustainable Development and World Ecology, 15, 231-239.

23. Geng, Y., Fu, J., Sarkis, J., Xue, B. 2012. Towards a national circular economy indicator system in China: an evaluation and critical analysis. Journal of Cleaner Production, 23(1), 216-224.

24. Ghisellini, P., Cialani, C., Ulgiati, S. 2016. A review on circular economy: the expected transition to a balanced interplay of environmental and economic systems. Journal of Cleaner Production, 114, 11-32.

25. Growth Within: A Circular Economy Vision for a Competitive Europe, Ellen MacArthur Foundation, SUM, McKinsey Center for Business and Environment, 2015, www.ellenmacarthurfoundation.org/assets/downloads/publications/EllenMacArthurFound ation_Growth-Within_July15.pdf, (Growth Within, 2015).

26. Guo, B., Geng, Y., Jingzheng, R., Zhu, L., Liu, Y., Sterr, T. 2017a. Comparative Assessment of Circular Economy Development in China's Four Megacities: The Case of 
Beijing, Chongqing, Shanghai and Urumqi. Journal of Cleaner Production. 162(20), 234246.

27. Guo, B., Geng, Y., Sterr, T., Zhu, Q., Liu, Y. 2017b. Investigating public awareness on circular economy in western China: A case of Urumqi Midong. Journal of Cleaner Production, 142, 2177-2186.

28. Hamari, J., Sjöklint, M., Ukkonen, A. 2016. The sharing economy: Why people participate in collaborative consumption. Journal of the Association for Information Science and Technology, 67(9), 2047-2059.

29. Homrich, A.S., Galvão, G., Abadia, L. G., Carvalho M. M., 2017. The Circular Economy Umbrella: Trends and Gaps on Integrating Pathways, Journal of Cleaner Production, 175, $525-543$.

30. Iacovidou, E., Millward-Hopkins, J., Busch, J., Purnell, P., Velis, C.,A., Hahladakis J. N., Zwirner O., Brown A, 2017. A pathway to circular economy: Developing a conceptual framework for complex value assessment of resources recovered from waste, Journal of Cleaner Production, 168,1279-1288.

31. Industrial Symbiosis for Regional Sustainable Growth and a Resource Efficient Circular Economy, SYMBI, 2015 (interregeurope.eu/symbi).

32. International Institute for Sustainable Development, 2017. Report from the World Circular Economy Forum, 2017, 208(20), enb.iisd.org/wcef/2017/html/enbplus208num20e (IISD, 2017).

33. Kanchanapibul, M., Lacka, E., Wang, X., Chan, H. K. 2014. An empirical investigation of green purchase behaviour among the young generation. Journal of Cleaner Production, 66, 528-536.

34. Kulczycka, J., Kowalski, Z., Smol, M., Wirth, H. 2016. Evaluation of the recovery of Rare Earth Elements (REE) from phosphogypsum waste-case study of the WIZÓW Chemical Plant (Poland). Journal of Cleaner Production, 113, 345-354.

35. Lakatos, E. S., Dan, V., Cioca, L. I., Bacali, L., Ciobanu, A. M. 2016. How supportive are Romanian consumers of the circular economy concept: A survey. Sustainability, 8(8), 789.

36. Małopolska Voivodship Assembly, 2017. Waste Management Plan for the Lesser Poland Region. Resolution No. XXXIV / 509/17 of Małopolska Voivodship Assembly from March 27, 2017 on amending the Resolution No. XI / 125/03 of Małopolska Region Assembly from 25 August 2003 on the Waste Management Plan of Małopolska Voivodship (MVA, 2017) (in Polish). 
37. Marshal Office of Malopolska Voivodeship, 2016, Voivodeship Labour Office in Cracow, Regional Center for Social Policy in Cracow, Malopolska Region Report (MOMV, 2016) (in Polish).

38. Liu, Q., Li, H.-m., Zuo, X.-1., Zhang, F.-f., Wang, L., 2009. A survey and analysis on public awareness and performance for promoting circular economy in China: a case study from Tianjin. Journal of Cleaner Production, 17, 265-270.

39. Liu, Y., Bai, Yi., 2014. An exploration of firms' awareness and behavior of developing circular economy: An empirical research in China. Resources, Conservation And Recycling, 87, 145-152.

40. McDowall, W., Geng, Y., Huang, B., Bartekova, E., Bleischwitz, R., Turkeli, S., Kemp, R., Domenech, T., 2017. Circular Economy Policies in China and Europe. Journal of Industrial Ecology, 21 (3), 651-661.

41. Murray, A., Skene, K., Haynes, K. 2017. The circular economy: An interdisciplinary exploration of the concept and application in a global context. Journal of Business Ethics, 140(3), 369-380.

42. Matuszak, A., Matuszak, Z. 2011. Definition of the sample and its size in pedagogical research. General and Professional Education, 2011(2), 33-39.

43. Noorhosseini, S. A., Allahyari, M. S., Damalas, C. A., Moghaddam, S. S. 2017. Public environmental awareness of water pollution from urban growth: The case of Zarjub and Goharrud rivers in Rasht, Iran. The Science of the total environment, 599, 2019.

44. Jiao, W., Boons, F. 2017. Policy durability of Circular Economy in China: A process analysis of policy translation. Resources, Conservation and Recycling, 117, 12-24.

45. Ośródka, L., Krajny, E., Klejnowski, K., Kozłowska, W. R., Błaszczyk, J., Kobus, D., Wypych, A. 2011. Air Quality Index as a measure of air pollution in Poland, Science Nature Technologies, 5(4), 43, 1-11.

46. Perdan, S., Jones, C. R., Azapagic, A. 2017. Public awareness and acceptance of carbon capture and utilisation in the UK. Sustainable Production and Consumption, 10, 74-84.

47. Regional Statistical Office in Cracow, 2014. Population and households report of the Malopolska region (RSO in Cracow, 2014) (in Polish).

48. Rakoczy, B. 2014. Organisation of municipal waste management in Polish law. Polish Yearbook of Environmental Law, (4), 57-69.

49. Roadmap Transformation towards a circular economy. Ministry of Development. Warsaw 2017 (Roadmap Transformation towards a circular economy, 2017) (in Polish). 
50. Saavedra, Y. M.B., Iritani, D. R., Pavan, A. L.R., Ometto, A. R., 2018. Theoretical contribution of industrial ecology to circular economy. Journal of Cleaner Production 170, 1514-1522.

51. Seppälä, J., Sahimaa, O., Honkatukia, J., Valve H., Antikainen, R., Kautto, P., Myllymaa, T., Mäenpää, I., Salmenperä, H., Alhola, K., Kauppila, J., Salminen, J. 2016. Kier totalous Suomessa - toimintaympäristö, ohjauskeinot ja mallinnetut vaikutukset vuoteen 2030 (Circular economy in Finland - operational environment, policy instruments and modelled impacts by 2030, in Finnish with English abstract).

52. Smol, M., Kulczycka, J., Avdiushchenko, A. 2017. Circular economy indicators in relation to eco-innovation in European regions. Clean Technologies and Environmental Policy, 19(3), 669-678.

53. Sonnemann, G., Gemechu, E. D., Adibi, N., De Bruille, V., Bulle, C. 2015. From a critical review to a conceptual framework for integrating the criticality of resources into Life Cycle Sustainability Assessment. Journal of Cleaner Production, 94, 20-34.

54. Special Eurobarometer 416, 2014. Attitudes of European citizens towards the environment. ec.europa.eu/commfrontoffice/publicopinion/archives/ebs/ebs_416_en.pdf

(Special Eurobarometer, 2014).

55. Toni, M., Renzi, M. F., Mattia, G. 2018. Understanding the link between collaborative economy and sustainable behaviour: An empirical investigation. Journal of Cleaner Production, 172, 4467-4477.

56. Towards a Circular Economy (2016), Ministry of the Environment, www.mos.gov.pl/en/news/details/controller/detail/News/news/towards-a-circulareconomy-1 (Towards a Circular Economy, 2016).

57. Tukker, A., 2015. Product services for a resource-efficient and circular economy - a review. Journal of Cleaner Production, 97, 76-91.

58. Voivodeship Inspectorate for Environmental Protection in Cracow, 2016, Report on the State of the Environment in Malopolska in the years 2013-2015 (VIEP in Cracow, 2016) (in Polish).

59. World Health Organization. Air quality in cities database 2016, www.who.int/phe/health_topics/outdoorair/databases/cities/en (WHO, 2016).

60. World Value Survey, 2017, www.worldvaluessurvey.org (World Value Survey, 2017)

61. Xue, B., Chen, X-p., Geng, Y., Guo, X-j., Lu, Ch-p., Zhang, Z-1., Luc, Ch-y., 2010. Survey of officials' awareness on circular economy development in China: Based on municipal and county level. Resources Conservation \& Recycling, 54, 1296-1302. 
62. Zeng, H., Chen, X., Xiao, X., Zhou, Z., 2017. Institutional pressures, sustainable supply chain management, and circular economy capability: Empirical evidence from Chinese ecoindustrial park firms. Journal of Cleaner Production, 155, 54-65.

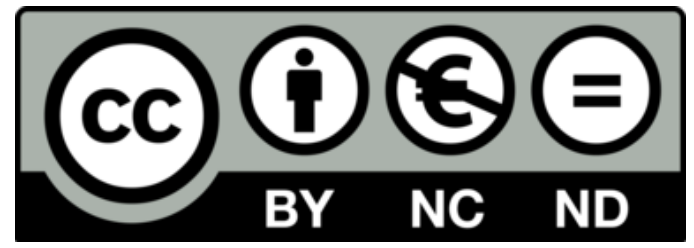

